\title{
Seasonality of the Airborne Ambient Soot Predominant Emission Sources Determined by Raman Microspectroscopy and Thermo-Optical Method
}

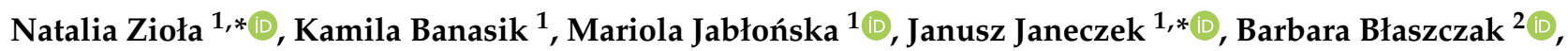 \\ Krzysztof Klejnowski ${ }^{2}$ (D) and Barbara Mathews ${ }^{2}$ \\ 1 Institute of Earth Sciences, University of Silesia, Będzińska 60, 41-200 Sosnowiec, Poland; \\ kamila.banasik@us.edu.pl (K.B.); mariola.jablonska@us.edu.pl (M.J.) \\ 2 Institute of Environmental Engineering of the Polish Academy of Sciences, 34 M. Skłodowska-Curie Str., \\ 41-819 Zabrze, Poland; barbara.blaszczak@ipis.zabrze.pl (B.B.); krzysztof.klejnowski@ipis.zabrze.pl (K.K.); \\ barbara.mathews@ipis.zabrze.pl (B.M.) \\ * Correspondence: nziola@us.edu.pl (N.Z.); janusz.janeczek@us.edu.pl (J.J.)
}

\section{check for} updates

Citation: Zioła, N.; Banasik, K.; Jabłońska, M.; Janeczek, J.; Błaszczak, B.; Klejnowski, K.; Mathews, B. Seasonality of the Airborne Ambient Soot Predominant Emission Sources Determined by Raman Microspectroscopy and Thermo-Optical Method. Atmosphere 2021, 12, 768. https://doi.org/ $10.3390 /$ atmos 12060768

Academic Editor: Darius Ceburnis

Received: 4 May 2021

Accepted: 11 June 2021

Published: 14 June 2021

Publisher's Note: MDPI stays neutral with regard to jurisdictional claims in published maps and institutional affiliations.

Copyright: (c) 2021 by the authors. Licensee MDPI, Basel, Switzerland. This article is an open access article distributed under the terms and conditions of the Creative Commons Attribution (CC BY) license (https:// creativecommons.org/licenses/by/ $4.0 /)$.

\begin{abstract}
Raman microspectroscopy and thermo-optical-transmittance (TOT) method were used to study airborne ambient soot collected at the suburban air monitoring station in southern Poland during the residential heating (January-February) and non-heating (June-July) seasons of 2017. Carbonaceous material constituted on average 47.2 wt.\% of $\mathrm{PM}_{2.5}$ during the heating season and $26.9 \mathrm{wt} . \%$ in the non-heating season. Average concentrations of OC $\left(37.5 \pm 11.0 \mu \mathrm{g} / \mathrm{m}^{3}\right)$ and EC $\left(5.3 \pm 1.1 \mu \mathrm{g} / \mathrm{m}^{3}\right)$ during the heating season were significantly higher than those in the non-heating season $\left(\mathrm{OC}=2.65 \pm 0.78 \mu \mathrm{g} / \mathrm{m}^{3}\right.$, and $\left.\mathrm{EC}=0.39 \pm 0.18 \mu \mathrm{g} / \mathrm{m}^{3}\right)$. OC was a chief contributor to the TC mass concentration regardless of the season. All Raman parameters indicated coal combustion and biomass burning were the predominant sources of soot in the heating season. Diesel soot, which is structurally less ordered than soot from other sources, was dominant during the non-heating season. The $\mathrm{D} 1$ and $\mathrm{G}$ bands area ratio $\left(\mathrm{D} 1_{\mathrm{A}} / \mathrm{G}_{\mathrm{A}}\right)$ was the most sensitive Raman parameter that discriminated between various soot sources, with $\mathrm{D} 1_{\mathrm{A}} / \mathrm{G}_{\mathrm{A}}>1$ for diesel soot, and less than 1 for soot from coal and wood burning. Due to high daily variability of both TOT and Raman spectroscopy data, single-day measurements can be inconclusive regarding the soot source apportionment. Long-time measurement campaigns are recommended.
\end{abstract}

Keywords: ambient soot; Raman spectroscopy; thermo-optical-transmittance analysis

\section{Introduction}

Carbonaceous matter (CM) is a common and important component of atmospheric aerosols, and accounts for $20-50 \%$ of the total aerosol mass [1]. CM consists of primary carbon-rich particles and of both primary and secondary organic compounds [2]. The primary carbon-rich particles are interchangeably called soot, black carbon (BC), or elemental carbon (EC). However, the term elemental carbon refers to thermally-refractory carbon and should be used only in conjunction with chemical or thermo-optical analyses [3-5]. Black carbon is a descriptive term of light-absorbing CM in atmospheric aerosol [6] that should be used only in reference to optical properties of CM. BC is the strongest light absorber per unit mass of all atmospheric aerosol species [7]. Due to the strong absorption of light combined with its omnipresence in the atmosphere, ambient BC is an important climate forcer [7]. BC should not be confused with carbon black, which is an industrial carbon material widely used in numerous applications [8].

Soot is the solid, carbon-rich material originating from incomplete combustion of fossil fuels and biomass burning. Soot is composed of fractal-like aggregates of spherical particles, usually smaller than $100 \mathrm{~nm}$, built of concentrically wrapped, graphene-like 
layers of carbon $[3,5,9]$. Upon atmospheric aging, the fractal-like aggregates of soot are restructured into more compact aggregates due to cloud processing [10]. Individual soot spherules within soot aggregates comprise turbostratic (wavy) graphitic layers with basal $\left(\mathrm{d}_{001}\right)$ spacings usually larger than $0.334 \mathrm{~nm}$, typical of ordered graphite [11]. Nanospheres of soot can be a major constituent of BC [3]. Hydrocarbons may occur in atmospheric soot particles in the form of small-sized aromatic moieties [12].

Some authors extend the term soot to a mixture of highly ordered (graphitic), disordered, and amorphous carbon with the addition of graphenes, fullerenes, and various hydrocarbons [13]. To avoid further confusion, the broad meaning of the term soot is used for the carbon material in $\mathrm{PM}_{2.5}$ that was collected and analyzed in this study, which is composed of soot particles and organic matter.

There are four major sources of soot emissions: transportation, industry, residential cooking and heating, and open burning. The latter is by far the largest source of soot at a global scale [3]. However, in developed countries about $70 \%$ of soot emission is due to diesel fuel combustion; whereas, in Africa and Asia coal and biomass burning accounts for $60 \%$ to $80 \%$ of soot emission [3]. In this respect, Poland, unlike most European countries, is exceptional because coal combustion for domestic purposes is a major soot source, particularly in winter [14].

The short- and long-term detrimental health effects of inhaled soot particles, including all-cause, cardiovascular, and cardiopulmonary mortality are well documented, e.g., $[15,16]$ and references therein. Moreover, soot particles may carry toxic substances adhered to their large sorption surface area [15].

Although the most detailed structural characterization of soot is obtained using high resolution transmission electron microscopy [12,17-21], Raman spectroscopy has increasingly been used to characterize soot of different origins, e.g., [13,22-24]. Raman spectroscopy has successfully been applied to study atmospheric CM [25-29]. Comparison of the Raman spectra of ambient $\mathrm{CM}$ with reference carbonaceous materials was a common approach in those studies.

One of the challenges in air quality study is to distinguish between different source categories of airborne soot and related CM. Raman spectroscopy appears to be well suited for this purpose. For instance, Catelani et al. [29] were able to distinguish between urban soot from soot collected at a rural-suburban site based on the differences in the full-width at half maximum (FWHM) and intensity ratio of the Raman bands.

Based on the structural characterization of anthropogenic (diesel engine soot, soot from coal and wood combustion) and atmospheric ( $\mathrm{PM}_{2.5}$-related soot) samples using Raman spectroscopy, we attempted to identify the season-depending predominant soot source category in an urbanized region of Silesia, southern Poland, which is known to have one of the greatest concentrations of air pollution in Europe. The thermo-opticaltransmittance method was used to check its consistency with Raman spectroscopy. The relationship between the quantitative determination of individual carbon fractions (organic and elemental) and the $\mathrm{I}_{\mathrm{D}} / \mathrm{I}_{\mathrm{G}}$ parameter suggests the usefulness of Raman spectroscopy in determining the quantitative content of soot.

\section{Sampling Site}

Ambient soot associated with $\mathrm{PM}_{2.5}$ was sampled at the suburban air monitoring station of the Institute of Meteorology and Water Management-National Research Institute, located at the outskirts of Racibórz, approximately $2.5 \mathrm{~km}$ from the city center $\left(50.06^{\circ} \mathrm{N}\right.$, $18.19^{\circ} \mathrm{E}$ ), in the south-western part of the Silesia province (voivodship), southern Poland (Figure 1). Racibórz is populated by about 55,000 inhabitants and is situated in the proximity of the large urban and industrial centers of Ostrava in the Czech Republic (ca. $30 \mathrm{~km}$ to the South), Upper Silesian Conurbation (approx. $70 \mathrm{~km}$ to the NE), and Rybnik industrial area (approx. $30 \mathrm{~km}$ to the E). Racibórz is an industrial city famous for its carbon electrode manufacturing. The sampling site is surrounded by arable fields and residential areas. Approximately $100 \mathrm{~m}$ to the east there is a high-traffic road. 


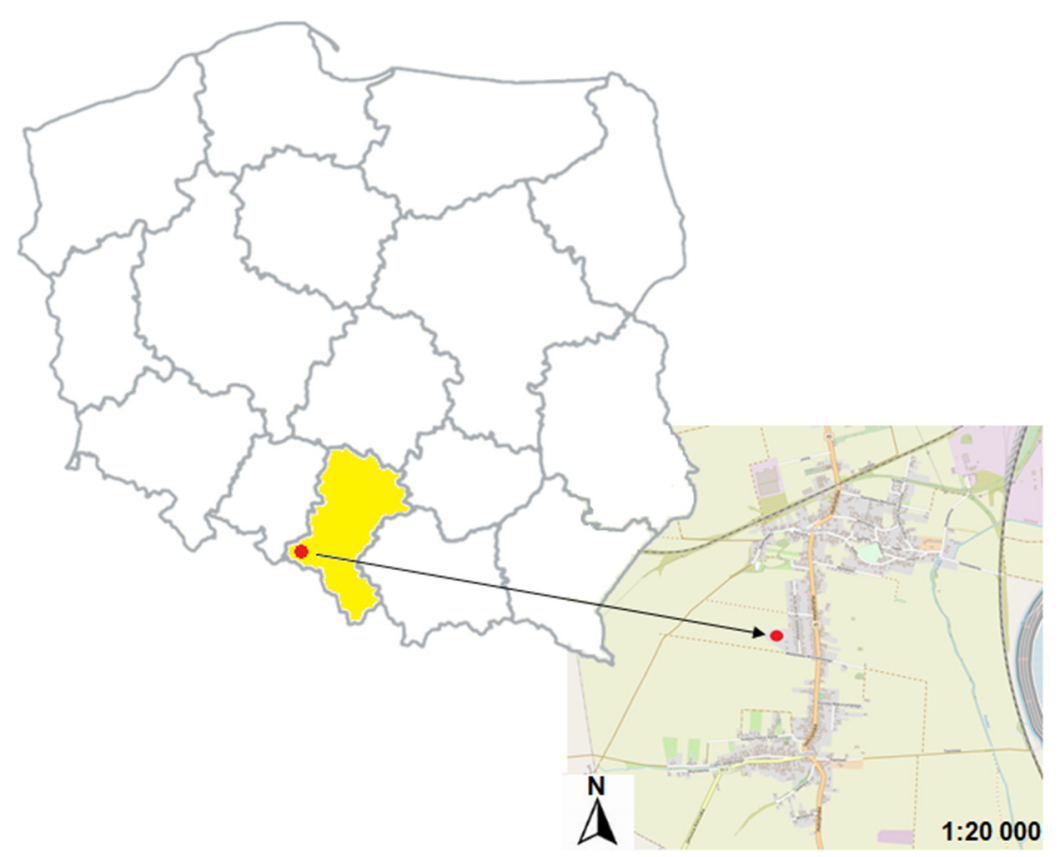

Figure 1. The sampling site location (red dot) in Racibórz in the Silesia province (yellow area on the map of Poland).

The mean annual concentrations of airborne $\mathrm{PM}_{2.5}$ range from 20 to $35 \mu \mathrm{g} / \mathrm{m}^{3}$ within about $90 \%$ of the Racibórz city limits; whereas, in the remaining part of the city, these concentrations are higher, up to $45 \mu \mathrm{g} / \mathrm{m}^{3}$ [30]. Diurnal concentrations of $\mathrm{PM}_{10}$ and $\mathrm{PM}_{2.5}$ in the winter heating season can be as high as 184 and $161 \mu \mathrm{g} / \mathrm{m}^{3}$, respectively, due to coal combustion for domestic purposes [30]. Little difference exists in poor air quality in winter between the Racibórz city center and the air monitoring station at the city's outskirts, as suggested by the number of days, 54 and 43 , respectively, with exceedances of the recommended value for the average daily $\mathrm{PM}_{2.5}$ concentration $\left(25 \mu \mathrm{g} / \mathrm{m}^{3}\right)$ [31]. The average $\mathrm{PM}_{2.5}$ concentrations in the heating season (late October-late April) and non-heating season of 2019 measured at suburban stations were $35(5-136) \mu \mathrm{g} / \mathrm{m}^{3}$ and 17 (4-65) $\mu \mathrm{g} / \mathrm{m}^{3}$, respectively [31]. The mean seasonal concentrations of $\mathrm{PM}_{2.5}$ recorded at the station located in the city center were comparable and amounted to $36(6-134) \mu \mathrm{g} / \mathrm{m}^{3}$ (heating season) and $16(6-43) \mu \mathrm{g} / \mathrm{m}^{3}$ (non-heating season).

There is a distinct seasonality of air pollution in Silesia caused by large-scale coal burning in winter [32]. Soot is the principal constituent of PM in winter, with maximum concentrations exceeding 90\% vol.; whereas, in summer, the soot content is in the $5-10 \%$ vol. range [14].

\section{Materials and Methods}

\subsection{Sample Description}

Four reference soot samples were collected from an exhaust pipe of a diesel-fueled car (sample E), two different wood-burning fireplaces (samples W1 and W2), and a coalburning home furnace (sample C). These are typical soot sources in the Silesia province and soot emitted from these sources is expected to predominate in ambient air. Ambient soot together with $\mathrm{PM}_{2.5}$ were collected on quartz filters (Whatman QMA) using a Low Volume Sampler (LVS) with the volumetric flow rate set to $2.3 \mathrm{~m}^{3} / \mathrm{h}$. Eight samples were collected during the heating season (January and February) and another 8 samples during the non-heating season (June-July) of 2017. The adopted division into these two specific periods, commonly used in the literature, was dictated primarily by differences in air temperatures and the resulting difference in heat demand and its consumption [31,32]. 


\subsection{Raman Spectroscopy}

Raman spectra were collected in the $100-4500 \mathrm{~cm}^{-1}$ range using a WITec alpha 300R confocal Raman microspectrometer equipped with an air-cooled solid-state laser and a CCD camera. The best quality spectra were obtained using the $488 \mathrm{~nm}$ excitation line. The excitation laser radiation was introduced into the microscope through a single-mode optical fiber with a diameter of $3.5 \mu \mathrm{m}$. Microscope objectives LD EC Epiplan-Neofluan DIC100/0.75NA; LD EC Epiplan-Neofluan DIC—50/0.55NA, and EC Epiplan-1/0.25NA were used. Raman scattered light was focused onto a single-mode optical fiber ( $30 \mu \mathrm{m}$ in diameter) and onto a monochromator with a $600 \mathrm{~mm}^{-1}$ diffraction grating. Raman spectra were accumulated by 10 scans with a single spectrum acquisition time of $10 \mathrm{~s}$ and a resolution of $3 \mathrm{~cm}^{-1}$. All Raman spectra were recorded during a single session under the same operating conditions because the laser beam power on the sample could not be measured.

Baseline correction and cosmic ray removal were performed using WITec Project software (version 4,1,12). Peak fitting was performed using the IFORS (Iterative Fitting of Raman Spectra) software [33]. Only the first order spectra in the range of 400 to $2200 \mathrm{~cm}^{-1}$ were used for the fitting procedure.

The automatic modeling of the background in IFORS is based on the fifth-order polynomial and the pseudo-Voigt (PV) functions. The sum of the functions and the polynomial is adjusted to the spectrum by randomly changing a single parameter (center, height, HWHM). When the parameters are optimized, the model adds more PV functions until the maximum number of PV functions is reached. Based on the sum of optimized PV functions, an accurate, corrected, and smoothed spectrum baseline is obtained. In subsequent mathematical processes, the scaled total area of the D ( $\left.\mathrm{D}_{\text {STA }}\right)$ and $G\left(\mathrm{G}_{\text {STA }}\right)$ bands is calculated [33]. IFORS is a software package dedicated to the study of carbonaceous substances and has been successfully used in earlier studies $[34,35]$. Statistical analyses were performed using the Stat Soft software package, Statistica 12.0.

\subsection{Thermal-Optical Transmittance (TOT) Analysis}

Organic carbon (OC) and elemental carbon (EC) in $\mathrm{PM}_{2.5}$ were determined using a Sunset Laboratory Inc. thermal-optical analyzer (Model 4L Main Oven Assembly) with flame ionization detector (FID). In TOT analysis, the carbonaceous component of PM collected on quartz-fiber filters evolves thermally during combustion at stepwise increases in temperature in accordance with the EUSAAR-2 temperature protocol (Table S1). The protocol was recommended as a standard method for European monitoring stations under the European Supersites for Atmospheric Aerosol Research (EUSAAR) project [4]. The procedure applied in this study is described in detail in [31]. The $1.0 \mathrm{~cm}^{2}$ section of each quartz filter with deposited $\mathrm{PM}_{2.5}$ was gradually heated in the inert atmosphere of $\mathrm{He}$ to release four temperature-resolved organic carbon fractions (OC1-4). Then, the filter sections were heated in an oxidizing helium-oxygen mixture to release four elemental carbon fractions (EC1-4). The carbon-bearing compounds released from the filter during the stepwise heating were converted to $\mathrm{CO}_{2}$ in an oxidizer oven in the presence of $\mathrm{MnO}_{2}$ catalyst. The $\mathrm{CO}_{2}$ was then reduced to methane in the methanator and its amount was measured by FID. During the inert mode of the analysis (heating in He) some organic compounds easily pyrolize into a refractory material called pyrolitic carbon (PC), which resembles EC [4]. During TOT analysis, the pyrolytic conversion of OC into PC is continuously monitored by measuring the transmission of a laser beam through the filter and the results are automatically corrected. After the correction for PC, the OC is obtained as: $\mathrm{OC}=\mathrm{OC} 1+\mathrm{OC} 2+\mathrm{OC} 3+\mathrm{OC} 4+\mathrm{PC}$; whereas $\mathrm{EC}=\mathrm{EC} 1+\mathrm{EC} 2+\mathrm{EC} 3+\mathrm{EC} 4-\mathrm{PC}$ [31] The total carbon (TC) content is the sum of OC and EC.

The measurement performance was controlled by regular split point determination for the pyrolytic carbon, in addition to systematic analysis of blank filters and calibration of the apparatus-periodic analysis of a calibration (control) sample of glucose solution of known concentration. In addition, the auto-calibration of the analyzer was conducted 
through the inclusion of a fixed volume loop used to inject an external standard (Air Liquide) at the end of each analysis. The total uncertainties in EC and OC measurements were of the order of $5 \%$ (at a 95\% confidence interval). The limits of detection (LOD) were 0.17 and $0.80 \mu \mathrm{g} / \mathrm{cm}^{2}$, respectively, for EC and OC. Moreover, certified reference materials (CRMs; RM 8785 and RM 8786; National Institute of Standards and Technology (NIST)) were periodically analyzed-recovery of $90-102 \%$ and $98-124 \%$ was obtained, respectively, for OC and EC.

\section{Results and Discussion}

\subsection{Mass Concentrations of $P M_{2.5}, O C$ and EC}

The mass concentration of $\mathrm{PM}_{2.5}$ collected during the heating season ranged from 65.29 to $119.08 \mu \mathrm{g} / \mathrm{m}^{3}$ (mean value $90.65 \pm 20 \mu \mathrm{g} / \mathrm{m}^{3}$ ) and was much higher than that in non-heating season samples $\left(7.5-14.5 \mu \mathrm{g} / \mathrm{m}^{3}\right.$; mean value $\left.11.025 \pm 2.44 \mu \mathrm{g} / \mathrm{m}^{3}\right)$ (Table S2). The high variability of $\mathrm{PM}_{2.5}$ concentrations, particularly in the heating season, most probably reflects changes in daily meteorological conditions. Nevertheless, $\mathrm{PM}_{2.5}$ mass concentrations throughout the sampling campaign in winter exceeded the daily limit value of $25 \mu \mathrm{g} / \mathrm{m}^{3}$.

$\mathrm{CM}$ on average constituted $47.17 \mathrm{wt} . \%$ of $\mathrm{PM}_{2.5}$ during the heating season and $26.93 \mathrm{wt} . \%$ in the non-heating season. Average concentrations of TC $\left(42.8 \pm 12.0 \mu \mathrm{g} / \mathrm{m}^{3}\right)$, $\mathrm{OC}\left(37.5 \pm 11.0 \mu \mathrm{g} / \mathrm{m}^{3}\right)$, and EC $\left(5.3 \pm 1.1 \mu \mathrm{g} / \mathrm{m}^{3}\right)$ during the heating season were 14 to 16 times higher than the values in the non-heating season (TC $=3.03 \pm 0.90 \mu \mathrm{g} / \mathrm{m}^{3}$, $\mathrm{OC}=2.65 \pm 0.78 \mu \mathrm{g} / \mathrm{m}^{3}$, and EC $=0.39 \pm 0.17 \mu \mathrm{g} / \mathrm{m}^{3}$ ) (Table S2). A significant increase in the concentration of $\mathrm{CM}$ in cold months is a common phenomenon in Poland due to widespread use of coal for household heating and cooking [36-38]. Poland, however, is not exceptional in this respect. Seasonal variability of carbonaceous aerosols with a peak mass concentrations in winter caused by human activities is commonly observed in countries with residential heating based on biomass burning and/or coal combustion, e.g., [39-46].

There is a strong positive correlation between OC and EC for the entire measurement periods and for the heating season $\left(\mathrm{R}^{2}=0.94\right)$; whereas, in the non-heating season the correlation is weak $\left(R^{2}=0.51\right)$ (Figure 2). A strong relationship between OC and EC suggests a dominant primary source of carbonaceous matter [39].

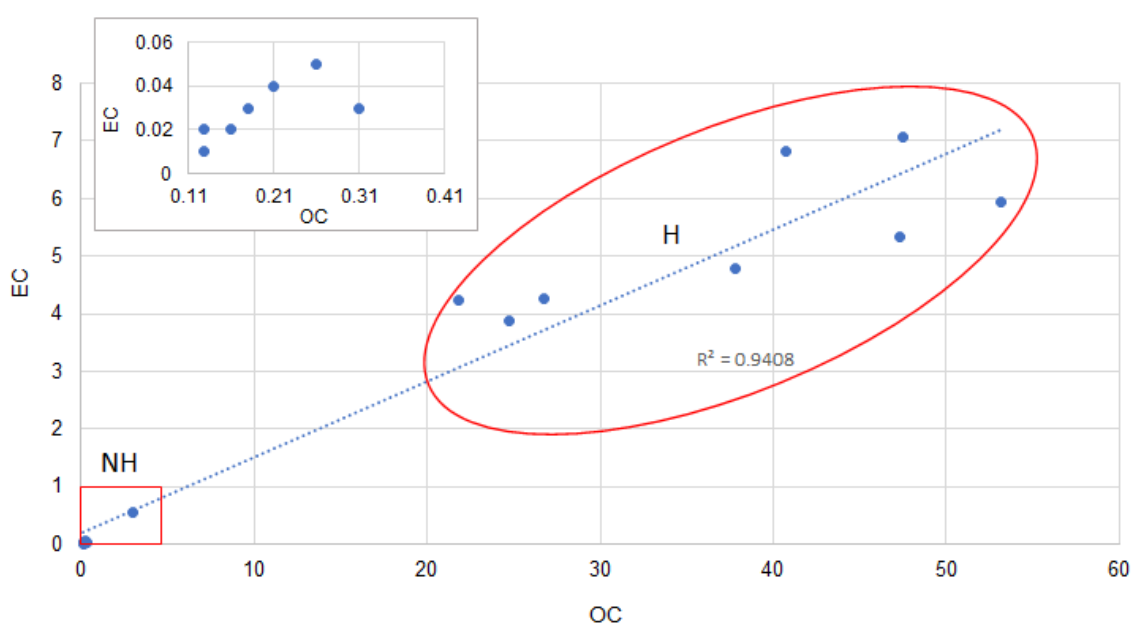

Figure 2. Relationship between OC and EC mass concentrations $\left(\mu \mathrm{g} / \mathrm{m}^{3}\right)$ during heating $(\mathrm{H})$ and non-heating (NH; see also enlarged view in the inset) seasons in Racibórz in 2017.

OC was a chief contributor to the TC regardless of the season (Table S2) and on average constituted $87.63 \mathrm{wt} . \%$ of TC during the heating season and $87.53 \mathrm{wt} . \%$ in summer samples. The average OC/EC ratio for samples from the heating season $(7.02 \pm 1.30)$ was slightly lower than that for the non-heating season $(7.44 \pm 2.05)$. However, individual OC/EC values varied significantly daily during both sampling periods (Table S2). The 
high OC/EC values in the heating season suggest an increased role of residential biomass burning in addition to coal combustion because fossil fuel burning is characterized by lower OC/EC values, which are often below unity [40]. The predominance of OC over EC in PM regardless of the season has been observed in several sites of southern Poland and was attributed to biomass burning throughout the year [31,32].

\subsection{Raman Spectroscopy}

\subsubsection{Generalities}

The unprocessed Raman spectra of soot and related carbonaceous materials consist of two intense first-order bands designated G and D bands. The G ("graphitic") band at around $1600 \mathrm{~cm}^{-1}$ corresponds to stretching vibrations of carbon-carbon $\mathrm{sp}^{2}$ bonds within graphene layers $[13,47]$. The D ("disorder" or "defect") band at around $1350 \mathrm{~cm}^{-1}$ results from structural and chemical defects in the graphitic structure [13]. The Raman spectrum of soot and related carbonaceous materials can be deconvoluted into two (D1 and D3) [48], three (D1, D3, D4) [49], four (D1-D4) [13], and five (D1-D5) [50] disordered bands. There may be additional bands in the Raman spectra of carbonaceous matter [50].

In addition to the band positions, the following Raman parameters were applied in the present study: the $D$ and $G$ bands scaled total area ( $D_{\text {STA }}$ and $G_{S T A}$ ) as defined in [33]; the $D$ and $G$ bands scaled total area ratio $\left(D_{\mathrm{STA}} / \mathrm{G}_{\mathrm{STA}}\right)$; the $\mathrm{D} 1$ and $\mathrm{G}$ bands area ratio $\left(\mathrm{D} 1_{\mathrm{A}} / \mathrm{G}_{\mathrm{A}}\right)$; the Raman area ratio (RAR) [33]; Raman band separation ( $R B S=G-D)$; the $D$ and $G$ bands height intensity ratio $\left(\mathrm{I}_{\mathrm{D}} / \mathrm{I}_{\mathrm{G}}\right)$; the $\mathrm{D} 1$ and $\mathrm{G}$ bands height intensity ratio $\left(\mathrm{I}_{\mathrm{D} 1} / \mathrm{I}_{\mathrm{G}}\right)$; and the G-band full width at half maximum $\left(\mathrm{FWHM}_{\mathrm{G}}\right)$. The D-band FWHM for all samples was $120 \mathrm{~cm}^{-1}$; hence, it was not useful for discriminating soot from different seasons.

\subsubsection{Reference Samples}

Unprocessed Raman spectra of all reference samples consist of two broad and overlapping $\mathrm{G}$ and $\mathrm{D}$ bands that are typical of disordered carbon (Figure 3). The D band centers in the $1340-1380 \mathrm{~cm}^{-1}$ range and the $G$ band in the $1580-1600 \mathrm{~cm}^{-1}$ range. Both bands in the spectrum of diesel soot (Figure 3d) are of almost equal maximum intensity, unlike in the other spectra, in which the G band is stronger than the D band (Figure 3a-c). The increase in the D-band intensity is considered to be a sign of increased disorder in the graphitic-type structure [13]. The diesel soot spectrum was deconvoluted into four broad band components (D1, D3, D4, and G). The spectra of soot from wood burning are more complex and were deconvoluted into five band components (D1, D3, D4, D5, and G) (Table 1; Figure 3a,b). The D5 band observed in the spectra of soot from both wood and coal combustion were probably caused by vibrations of aliphatic hydrocarbons [51,52]. In the spectrum of soot originated from coal combustion, there is an additional weak and very broad band centered at $1303 \mathrm{~cm}^{-1}$, designated D6 (Figure 3d). The D6 band can be attributed to hydrocarbons trapped in micropores of carbonaceous material [53].

The D2 component commonly observed as the shoulder on the G band at around $1620 \mathrm{~cm}^{-1}$ and attributed to structural disorder [13] was not resolved during the curve fitting in this study. It is possible that the low crystallinity of the investigated samples, and the resulting low G-band intensity, did not allow the relatively weak D2 band to be distinguished from the $G$ band, as suggested by Beyssac et al. [54].

The Raman shift of D and G bands and the band separation are not specific for any type of the reference soot (Table 1). They are therefore not useful as indicators of the source of soot in the atmospheric air. Other parameters are considerably more sensitive in this respect (Table 2). 


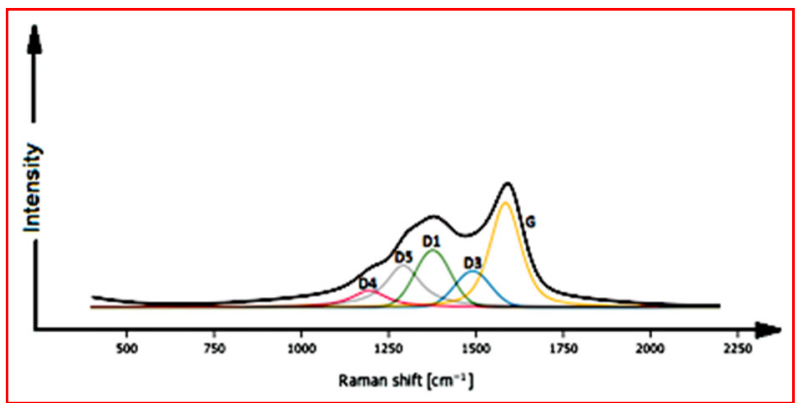

(a)

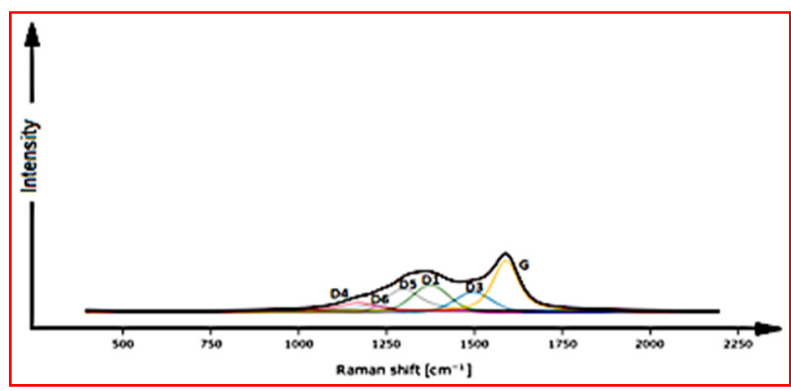

(c)

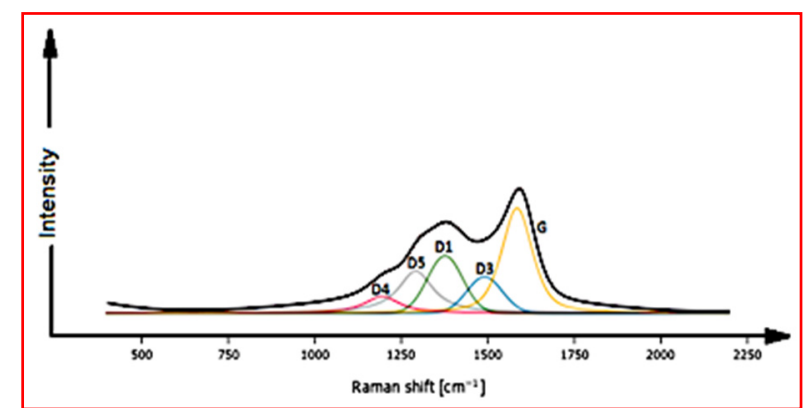

(b)

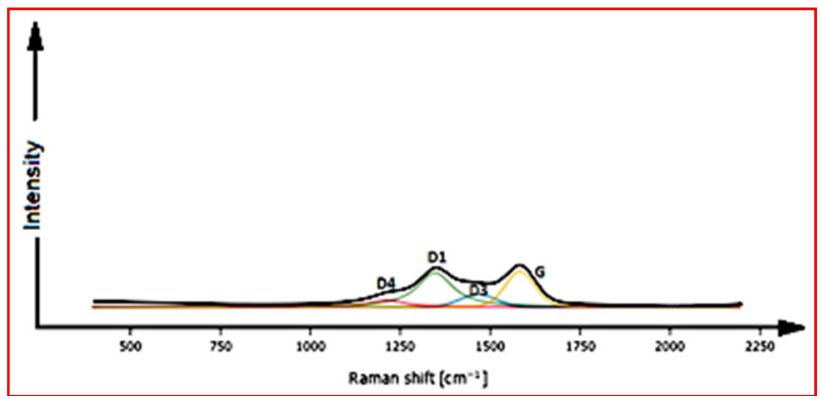

(d)

Figure 3. Deconvoluted Raman spectra of soot from wood combustion (samples W1 (a) and W2 (b)), coal-fired furnace (c), and diesel engine exhaust $(\mathbf{d})$.

Table 1. Curve-fitting results of Raman spectra $\left(\mathrm{cm}^{-1}\right)$ of the reference soot from wood burning (W1 and W2), coal-fired furnace (C), and tail-pipe diesel exhaust (E).

\begin{tabular}{cccccccccc}
\hline Sample & D $^{*}$ & G $^{*}$ & D1 & D2 & D3 & D4 & D5 & D6 & G \\
\hline W1 & 1356 & 1589 & 1380 & - & 1494 & 1196 & 1294 & - & 1586 \\
W2 & 1367 & 1595 & 1364 & - & 1499 & 1192 & 1278 & - & 1594 \\
C & 1337 & 1598 & 1382 & - & 1502 & 1238 & 1303 & 1174 & 1594 \\
E & 1353 & 1595 & 1353 & - & 1472 & 1218 & - & - & 1589 \\
\hline
\end{tabular}

* Band shifts measured in the unprocessed spectra.

Table 2. Raman parameters of the reference soot from wood burning (W1 and W2), coal-fired furnace (C), and tail-pipe diesel exhaust (E). RBS and $\mathrm{FWHM}_{\mathrm{G}}$ are in $\mathrm{cm}^{-1}$.

\begin{tabular}{ccccccccccc}
\hline Sample & $\mathbf{D}_{\text {STA }}$ & Std & $\mathbf{G}_{\mathbf{S T A}}$ & Std & D $_{\mathbf{S T A}} / \mathbf{G}_{\mathbf{S T A}}$ & $\mathbf{D 1}_{\mathbf{A}} / \mathbf{G}_{\mathbf{A}}$ & $\mathbf{R A R}$ & RBS & FWHM $_{\mathbf{G}}$ & I $_{\mathbf{D}} / \mathbf{I}_{\mathbf{G}}$ \\
\hline $\mathrm{W} 1$ & 286.128 & 0.535 & 199.476 & 0.070 & 1.43 & 0.51 & 4.04 & 233 & 106 & 0.69 \\
W2 & 275.838 & 0.036 & 195.904 & 0.172 & 1.41 & 0.59 & 3.57 & 228 & 88 & 0.70 \\
C & 286.043 & 0.254 & 195.294 & 0.033 & 1.46 & 0.56 & 4.31 & 261 & 86 & 0.67 \\
E & 218.924 & 0.052 & 205.596 & 0.015 & 1.06 & 1.57 & 1.10 & 242 & 96 & 0.97 \\
\hline
\end{tabular}

$\mathrm{D}_{\mathrm{STA}}$ and $\mathrm{GSTA}_{\mathrm{STA}}$-scaled total area of D and G bands, respectively; Std-standard deviation; $\mathrm{DST}_{\mathrm{A}} / \mathrm{GST}_{\mathrm{A}}-\mathrm{D}$ and $\mathrm{G}$ bands area ratio, $\mathrm{D} 1_{\mathrm{A}} / \mathrm{G}_{\mathrm{A}}-\mathrm{D} 1$ and $\mathrm{G}$ bands area ratio; RAR-Raman area ratio; RBS-Raman band separation, FWHM $_{\mathrm{G}}$-Full width at half maximum.

The height intensity ratio of $\mathrm{D}$ and $\mathrm{G}$ bands $\left(\mathrm{I}_{\mathrm{D}} / \mathrm{I}_{\mathrm{G}}\right)$ is a sensitive measure of soot crystallinity, i.e., the size of graphitic domains $[7,13]$. The $\mathrm{I}_{\mathrm{D}} / \mathrm{I}_{\mathrm{G}}$ ratio depends on numerous factors, including aromatic layer size, soot oxidation reactivity, maturation of coals, aging of diesel soot at various temperature, and fuel to oxygen ratio ([24] and references therein). The $\mathrm{I}_{\mathrm{D}} / \mathrm{I}_{\mathrm{G}}$ ratio is close to unity (0.97) for the reference diesel soot; whereas, soot from other sources show significantly lower $\mathrm{I}_{\mathrm{D}} / \mathrm{I}_{\mathrm{G}}$ ratios $(0.67-0.70)$ (Table 2$)$. The diesel soot spectrum is characterized by a similar height intensity of the D and $G$ bands (Figure $3 \mathrm{~d}$ ), which was not observed for the other spectra, in which the height intensity of the D band is significantly lower than that of the $\mathrm{G}$ band. This observation is consistent with previous investigation that showed a high amorphous to graphitic carbon ratio in diesel soot $[24,55]$. 
Diesel engine soot may have a higher degree of disorder (high amorphous to graphitic carbon ratio) compared to gasoline soot [24]. The four component bands observed in the spectrum of the reference diesel soot (Figure 3d) have been also reported in other studies [55-59]. Therefore, it can be considered that this is a characteristic feature of diesel soot. Some authors, however, distinguished three component bands in Raman spectra of both diesel and gasoline soot $[24,49]$.

The $\mathrm{I}_{\mathrm{D}} / \mathrm{I}_{\mathrm{G}}$ ratio of soot from coal combustion (0.67) is only slightly lower than that of soot originating during wood burning (0.69-0.70) (Table 2).

The $\mathrm{FWHM}_{\mathrm{G}}$ of diesel soot $\left(96 \mathrm{~cm}^{-1}\right)$ is significantly higher than that of soot from other sources, except for sample W1 (Table 2). There is an inverse relation between the FWHM of the Raman bands and the degree of crystallinity of CM $[13,25,27,29]$. There is a noticeable difference in $\mathrm{FWHM}_{\mathrm{G}}$ of soot originating from burning of different types of wood. Apparently, the crystallinity of the W1 soot is lower than that of W2.

The most distinct differences in Raman spectra of diesel soot and soot from other sources are revealed by the $\mathrm{D} 1_{\mathrm{A}} / \mathrm{G}_{\mathrm{A}}, \mathrm{D}_{\mathrm{STA}} / \mathrm{G}_{\mathrm{STA}}$, and RAR parameters (Table 2). The $\mathrm{D}_{\mathrm{STA}} / \mathrm{G}_{\mathrm{STA}}$ ratio is higher in the spectra of soot from wood and coal-burning than diesel soot. The $D_{\text {STA }} / G_{S T A}$ ratio increases with increasing order in the structure of CM [60]. The $D 1_{A} / G_{A}$ value (1.57) of diesel soot is between 2.7 and 3 times higher than that for wood- and coal-derived soot (Table 2). The $\mathrm{D} 1_{\mathrm{A}} / \mathrm{G}_{\mathrm{A}}$ ratio decreases with the increase in the degree of order in the carbonaceous material [61]. The $\mathrm{D} 1_{\mathrm{A}} / \mathrm{G}_{\mathrm{A}}$ ratio most distinctly differentiates between poorly ordered diesel soot $\left(D 1_{A} / G_{A}>1\right)$ and soot form other sources $\left(\mathrm{D} 1_{\mathrm{A}} / \mathrm{G}_{\mathrm{A}}<<1\right)$.

All of the Raman parameters are indicative of low crystallinity of the reference diesel soot compared to coal and wood soot, most probably as a result of higher content of amorphous carbon in the former.

\subsubsection{Ambient Soot}

Raman spectra of ambient soot collected during the heating season (Figure $4 \mathrm{a}$ and Figure S1) are similar in shape to those of the reference soot originating from coal and biomass burning (Figure 3a-c); whereas, Raman spectra of soot collected during the non-heating season (Figure $4 \mathrm{~b}$ and Figure S1) match the reference spectrum of poorly ordered diesel soot (Figure 3d). These similarities are further confirmed by all of the Raman parameters (Table S3). The $\mathrm{D} 1_{\mathrm{A}} / \mathrm{G}_{\mathrm{A}}$ and RAR parameters show the most distinct differences between samples from both seasons despite high variability of the daily data (Figure 5).

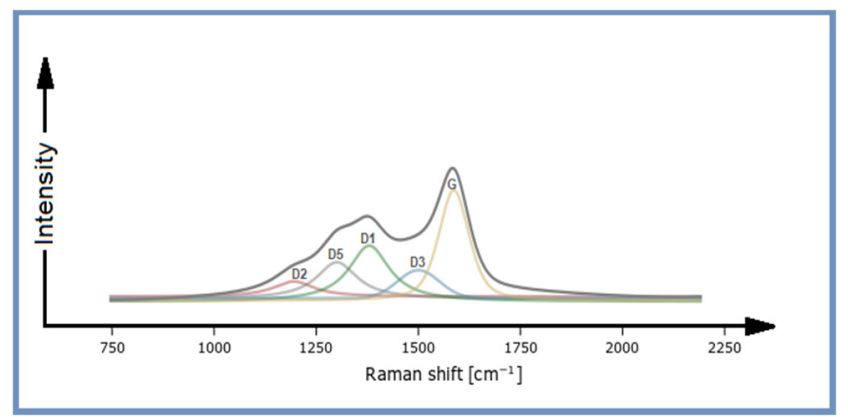

(a)

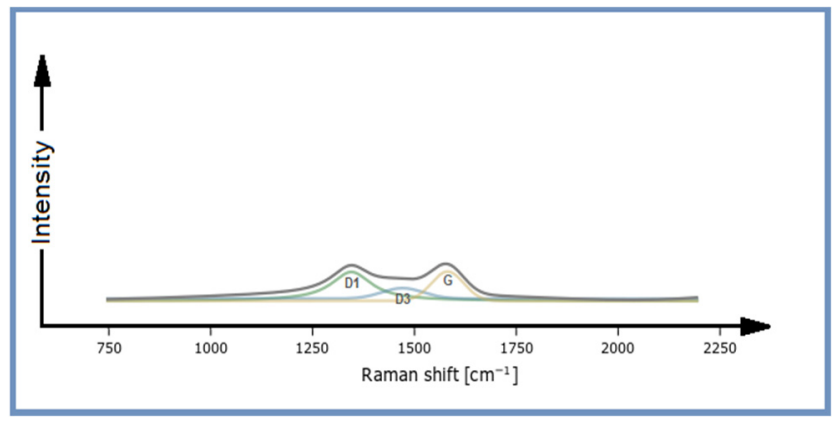

(b)

Figure 4. Exemplary deconvoluted Raman spectra of soot in $\mathrm{PM}_{2.5}$ collected during heating (H3) (a) and non-heating (NH4) (b) seasons in Racibórz. 


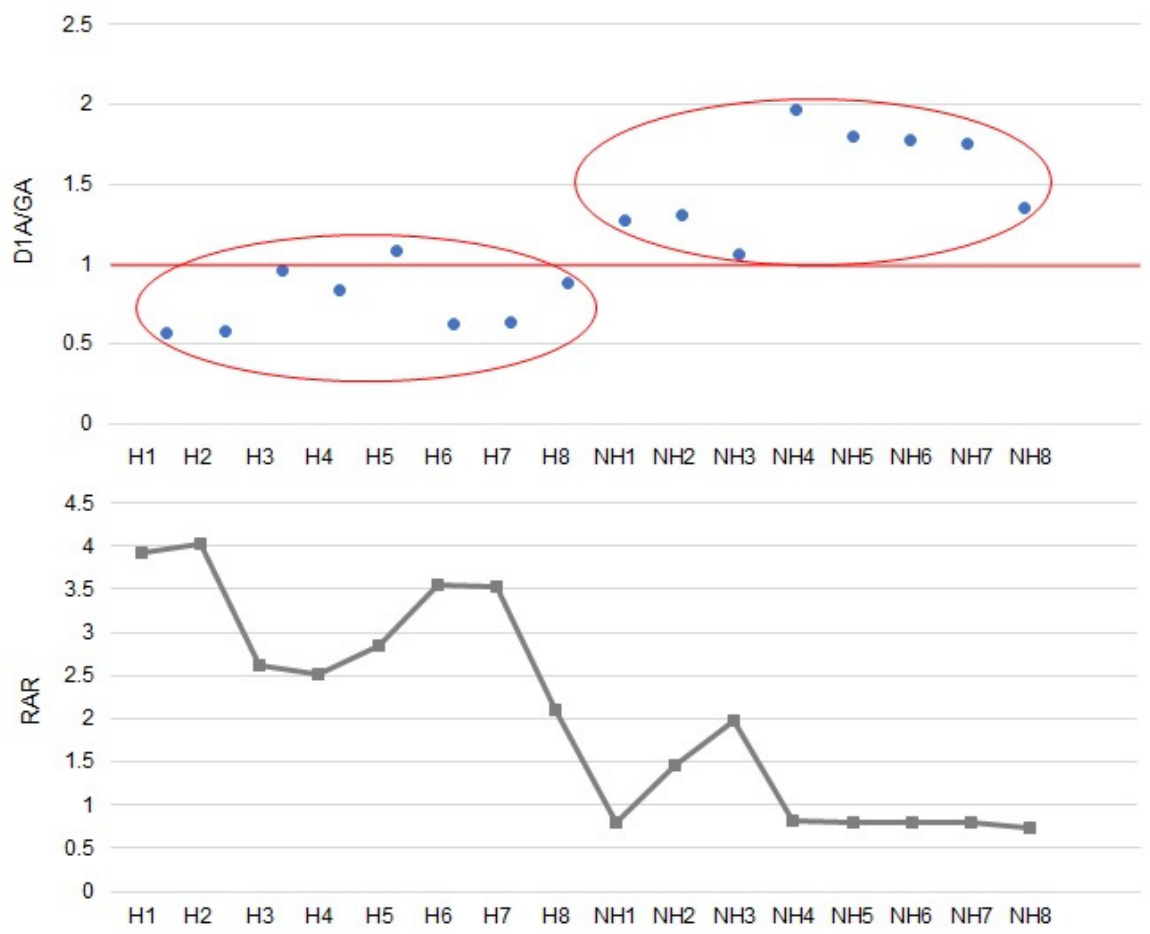

Figure 5. Season-dependent changes in the $\mathrm{D} 1_{\mathrm{STA}} / \mathrm{G}_{\mathrm{STA}}$ and RAR parameters in the Raman spectra of soot from Racibórz in 2017. H-heating season and NH non-heating season.

The RAR parameter for samples from the heating season was in the range of 2.10-4.02, and the $D 1_{A} / G_{A}$ ratio ranged from 0.57 to 0.96 (on average $0.77 \pm 0.18$ ). The comparison of these values with data for the reference material (Table 2) unequivocally points to soot derived from coal and wood (biomass) as being a predominant component of the investigated samples. The RAR for samples from the non-heating season was in the range of $0.74-1.97$ (average $1.02 \pm 0.42$ ), whereas the $\mathrm{D} 1_{\mathrm{A}} / \mathrm{G}_{\mathrm{A}}$ ranged from 1.06 to 1.96 (average $1.53 \pm 0.30$ ). These values are very close to those of diesel soot (Table 2).

Raman spectra of samples from the heating season are characterized by significantly weaker and broader D band than $\mathrm{G}$ band (Figure 4). The D band has a much larger area, ranging from 267 to 295, compared to the G band (170-199) (Table S3). The opposite relations between the $\mathrm{D}$ and $\mathrm{G}$ bands were observed in the Raman spectra of samples from the non-heating season (Figure 4 and Table S3). The D band is less pronounced and its area is in the range of 192-257 comparable to the G band (174-226) making the two main bands similar in size and shape. Average values of G-band area are similar for soot from heating (186) and non-heating (183) seasons (Table S3).

The $\mathrm{D}_{\mathrm{STA}} / \mathrm{G}_{\mathrm{STA}}$ ratio is distinctly higher for samples from the heating season (1.41-1.68, on average $1.53 \pm 09)$ than for the non-heating season (1.09-1.24, on average $1.13 \pm 04)$ and is similar to the $\mathrm{D}_{\mathrm{STA}} / \mathrm{G}_{\mathrm{STA}}$ ratio for soot originating from coal combustion (1.47) and wood burning (1.44-1.47); whereas, values for the non-heating samples are close to the $\mathrm{D}_{\mathrm{STA}} / \mathrm{G}_{\mathrm{STA}}$ ratio of diesel soot (1.06).

The mean $\mathrm{I}_{\mathrm{D}} / \mathrm{I}_{\mathrm{G}}$ ratio of soot collected during heating season (0.66) is close to the reference soot from both coal combustion $\left(\mathrm{I}_{\mathrm{D}} / \mathrm{I}_{\mathrm{G}}=0.67\right)$ and wood burning $\left(\mathrm{I}_{\mathrm{D}} / \mathrm{I}_{\mathrm{G}}=0.69\right)$; whereas the mean $\mathrm{I}_{\mathrm{D}} / \mathrm{I}_{\mathrm{G}}$ of soot collected during the non-heating season $(0.86)$ suggests the prevalence of diesel engine exhaust $\left(\mathrm{I}_{\mathrm{D}} / \mathrm{I}_{\mathrm{G}}=0.97\right.$ in Table 2$)$ with a probable contribution from gasoline engine exhaust. Gasoline soot has a lower D/G intensity ratio compared to diesel soot [24].

The average value of $\mathrm{FWHM}_{\mathrm{G}}$ for the heating season soot $\left(87 \pm 6 \mathrm{~cm}^{-1}\right.$; median $\left.83 \mathrm{~cm}^{-1}\right)$ is significantly lower than for the summer samples $\left(97 \pm 12 \mathrm{~cm}^{-1}\right.$; median $\left.99 \mathrm{~cm}^{-1}\right)$. Individual values of $\mathrm{FWHM}_{\mathrm{G}}$ deviate much more significantly from the average than those of $\mathrm{I}_{\mathrm{D}} / \mathrm{I}_{\mathrm{G}}$ (Table S3). 
In the heating season, the $\mathrm{I}_{\mathrm{D}} / \mathrm{I}_{\mathrm{G}}$ ratio follows the changes in $\mathrm{FWHM}_{\mathrm{G}}$, whereas during the non-heating season, both parameters behave differently. This observation is confirmed by Spearman's rank correlation $(\alpha=0.05)$. The correlation between $\mathrm{I}_{\mathrm{D}} / \mathrm{I}_{\mathrm{G}}$ and FWHM $_{\mathrm{G}}$ was positive $(\mathrm{r}=0.50)$ during the entire measurement period and was particularly strong $(r=0.85)$ during the heating season. In the non-heating season the correlation was lower and statistically insignificant $(\mathrm{r}=0.43)$. The correlation analysis shows that, as the degree of disorder in the soot structure increases, the correlation between the $\mathrm{I}_{\mathrm{D}} / \mathrm{I}_{\mathrm{G}}$ and FWHM $_{\mathrm{G}}$ weakens.

\subsection{Relations between Raman $I_{D} / I_{G}$ Parameter and TOT Data}

A correlation matrix between $\mathrm{I}_{\mathrm{D}} / \mathrm{I}_{\mathrm{G}}$ and $\mathrm{PM}_{2.5}, \mathrm{OC}, \mathrm{EC}$, and TC was computed for the entire measurement period and separately for heating and non-heating seasons (Table S4). In the entire measurement period, the highest negative correlation occurred between $\mathrm{I}_{\mathrm{D}} / \mathrm{I}_{\mathrm{G}}$ and $\mathrm{PM}_{2.5}(\mathrm{r}=-0.92)$. Strong negative correlations were also recorded between $\mathrm{I}_{\mathrm{D}} / \mathrm{I}_{\mathrm{G}}$ and $\mathrm{OC}, \mathrm{EC}$, and TC $(\mathrm{r}=-0.91)$. Considering the $\mathrm{OC}$ and $\mathrm{EC}$ thermally evolved fractions, high correlations between $\mathrm{I}_{\mathrm{D}} / \mathrm{I}_{\mathrm{G}}$ and EC3, OC3, and OC4 were observed $(\mathrm{r}=0.92$, 0.91 and 0.90 , respectively).

Correlations between $\mathrm{I}_{\mathrm{D}} / \mathrm{I}_{\mathrm{G}}$ and $\mathrm{OC}, \mathrm{EC}, \mathrm{TC}$, and $\mathrm{PM}_{2.5}$ in the heating season were statistically significant $(\mathrm{r}=-0.78, \mathrm{r}=-0.76, \mathrm{r}=-0.78$ and $\mathrm{r}=0.71$, respectively) but weaker than correlations for the entire sampling period. For the thermally evolved fractions of the OC and EC components, the highest correlation was between $\mathrm{I}_{\mathrm{D}} / \mathrm{I}_{\mathrm{G}}$ and $\mathrm{EC} 3(\mathrm{r}=-0.81)$. A high correlation ( $\mathrm{r}$ from -0.71 to -0.78 ) was also observed for EC2, EC1, and OC3. For other components, the correlations were statistically insignificant. In the non-heating season, a statistically significant correlation occurred only between $\mathrm{I}_{\mathrm{D}} / \mathrm{I}_{\mathrm{G}}$ and $\mathrm{EC} 4(\mathrm{r}=-0.71)$.

Statistical analyses showed that there is a high correlation between the degree of order in the soot structure and the content of individual carbon fractions, which is particularly noticeable throughout the entire measurement period. In this case, very high $\mathrm{I}_{\mathrm{D}} / \mathrm{I}_{\mathrm{G}}$ correlations were observed for both $\mathrm{OC}$ and $\mathrm{EC}$. The highest correlations were between $\mathrm{I}_{\mathrm{D}} / \mathrm{I}_{\mathrm{G}}$ and $\mathrm{EC} 3$ and between $\mathrm{I}_{\mathrm{D}} / \mathrm{I}_{\mathrm{G}}$ and OC3, whereas the lowest was between $\mathrm{I}_{\mathrm{D}} / \mathrm{I}_{\mathrm{G}}$ and $\mathrm{EC} 4$. The distribution of correlations suggests that the soot throughout the entire measurement period originated from sources with the temperature range of $450-700{ }^{\circ} \mathrm{C}$. During the heating season, the correlations between $\mathrm{I}_{\mathrm{D}} / \mathrm{I}_{\mathrm{G}}$ and $\mathrm{OC}$ and $\mathrm{EC}$ were lower.

In the non-heating season, a statistically significant correlation occurred only between $\mathrm{I}_{\mathrm{D}} / \mathrm{I}_{\mathrm{G}}(0.77-0.98)$ and EC4 $(\mathrm{r}=-0.74)$, which suggests the influence of vehicular transport as a major soot source.

Raman spectroscopy cannot distinguish between coal-combustion soot and soot originating from wood burning in ambient air samples; alternatively, other methods, namely determination of biomass burning tracers, i.e., levoglucosan, OC, OC/EC, and K, should be used.

Results obtained during this study are not entirely unexpected. The soot emission from coal combustion for domestic purposes in Silesia is extremally high in winter compared to vehicular soot emission, e.g., [37]. Moreover, vehicular traffic in Poland is about 20\% lower in winter than in summer [62]. Apparently, the occurrence of diesel soot in winter samples is masked by the abundant soot that originates during incomplete coal combustion and biomass burning. The decline in coal combustion for domestic purposes in summer results in a relative increase in the amount of airborne diesel soot. However, there is still some contribution from biomass and coal burning, as reflected in the lower $\mathrm{I}_{\mathrm{D}} / \mathrm{I}_{\mathrm{G}}$ ratio than expected for diesel soot. There may also be some contribution of the gasoline soot to Raman spectra of CM. Although this option was not explored during this study, it requires further consideration.

\section{Conclusions}

Raman parameters can reliably be used for distinguishing between diesel soot and soot from coal and wood combustion in ambient air samples. The $D 1_{A} / G_{A}$ ratio is the 
most sensitive parameter, with values higher than 1 for diesel soot and much lower than 1 for soot from both coal and wood burning. However, other Raman parameters also consistently indicated that coal combustion and biomass burning were the predominant sources of soot in the heating season. Diesel soot, which is structurally less ordered than soot from other sources, was dominant during the non-heating season. The strongest negative correlation occurred between $\mathrm{I}_{\mathrm{D}} / \mathrm{I}_{\mathrm{G}}$ and the highest temperature $\left(850^{\circ} \mathrm{C}\right)$ fraction EC4 for soot from the non-heating season, which confirms results of Raman spectroscopy that indicate vehicular transport is a major soot source.

Strong correlations between the coefficients obtained from both methods confirm the high efficiency of Raman spectroscopy as a method compatible with the TOT method, which is commonly used in air quality research.

Due to the high daily variability of both TOT and Raman spectroscopy data, single-day measurements can be inconclusive regarding the soot source apportionment. Long-time measurements are recommended for this purpose.

Supplementary Materials: The following are available online at https:/ / www.mdpi.com/article/10 .3390 /atmos12060768/s1, Figure S1: Raman spectra of soot in $\mathrm{PM}_{2.5}$ collected in Racibórz during heating $(\mathrm{H})$ and non-heating $(\mathrm{NH})$ seasons. Table S1. EUSAAR-2 temperature protocol used in thermal-optical-transmittance analysis; Table S2. Mass concentrations $\left(\mu \mathrm{g} \mathrm{m}^{-3}\right)$ of $\mathrm{PM}_{2.5}$; Table S3. Raman parameters obtained from the deconvolution of D and G bands in the spectra of soot collected during heating and non-heating seasons in Racibórz; Table S4. Nonparametric (Spearman) correlation matrix $(\alpha=0.05)$ for ID/IG and concentrations of OC, EC (including their thermally evolved components), TC, pyrolitic product $(\mathrm{Pyr})$, and $\mathrm{PM}_{2.5}\left(\mu \mathrm{g} \cdot \mathrm{m}^{-3}\right)$ calculated for the entire sampling period, and separately for the heating and non-heating seasons.

Author Contributions: Conceptualization, J.J., M.J. and N.Z.; methodology, J.J., N.Z., K.K.; formal analysis, N.Z., K.B., J.J., M.J., K.K., B.B., B.M.; investigation, N.Z., K.B., K.K., B.B., B.M.; resources, J.J., K.K.; data curation, M.J., K.K.; writing—original draft preparation, J.J., N.Z.; writing-review and editing, J.J., B.B., N.Z.; visualization, N.Z.; supervision, J.J.; funding acquisition, J.J., K.K., M.J. All authors have read and agreed to the published version of the manuscript.

Funding: This work was supported by the Institute of Earth Sciences of the University of Silesia in Katowice statutory research project no. WNP/INoZ/2020_ZB10 ("Gaseous and particulate pollutions in the tropospheric mixing layer and their impact on environment and human health") and by the Institute of Environmental Engineering of the Polish Academy of Sciences statutory research project no. 1a-128/2021 ("Primary and secondary components of the atmospheric aerosol in the context of the impact on the climate and natural environment of urban and non-urban areas"). The work was also prepared as a part of the research project no. POIR.04.02.00-00-D019/20-00 "ACTRIS-Infrastructure for the study of aerosols, clouds and trace gases", implemented under Measure 4.2 of the Smart Growth Operational Program 2014-2020 co-financed by the European Regional Development Fund.

Institutional Review Board Statement: Not applicable.

Informed Consent Statement: Not applicable.

Data Availability Statement: Data supporting reported results can be found in the data repository of the Institute of Earth Sciences, University of Silesia in Katowice.

Acknowledgments: We thank two anonymous reviewers for critical and valuable comments that considerably improved the final version of the manuscript.

Conflicts of Interest: The authors declare no conflict of interest. The funders had no role in the design of the study; in the collection, analyses, or interpretation of data; in the writing of the manuscript, or in the decision to publish the results.

\section{References}

1. Contini, D.; Vecchi, R.; Viana, M. Carbonaceous aerosols in the atmosphere. Atmosphere 2018, 9, 181. [CrossRef]

2. Tomasi, C.; Lupi, A. Primary and secondary sources of atmospheric aerosol. In Atmospheric Aerosols. Life Cycles and Effects on Air Quality and Climate; Tomasi, C., Fuzzi, S., Kokhanovsky, A., Eds.; Wiley Series in Atmospheric Physics and Remote Sensing; Wiley-VCH Verlag GmbH \& Co. KgaA: Weinheim, Germany, 2017; pp. 1-86. 
3. Buseck, P.R.; Adachi, K.; Gelencsér, A.; Tompa, É.; Pósfai, M. Are black carbon and soot the same? Atmos. Chem. Phys. Discuss. 2012, 12, 24821-24846. [CrossRef]

4. Karanasiou, A.; Minguillón, M.C.; Viana, M.; Alastuey, A.; Putaud, J.-P.; Maenhaut, W.; Panteliadis, P.; Močnik, G.; Favez, O.; Kuhlbusch, T.A.J. Thermal-optical analysis for the measurement of elemental carbon (EC) and organic carbon (OC) in ambient air: A literature review. Atmos. Meas. Tech. Discuss. 2015, 8, 9649-9712. [CrossRef]

5. Gilardoni, S.; Fuzzi, S. Chemical composition of aerosols of different origin. In Atmospheric Aerosols. Life Cycles and Effects on Air Quality and Climate; Tomasi, C., Fuzzi, S., Kokhanovsky, A., Eds.; Wiley Series in Atmospheric Physics and Remote Sensing; Wiley-VCH Verlag GmbH \& Co. KgaA: Weinheim, Germany, 2017; pp. 183-221.

6. Petzold, A.; Ogren, J.A.; Fiebig, M.; Laj, P.; Li, S.-M.; Baltensperger, U.; Holzer-Popp, T.; Kinne, S.; Pappalardo, G.; Sugimoto, N.; et al. Recommendations for reporting "black carbon" measurements. Atmos. Chem. Phys. 2013, 13, 8365-8379. [CrossRef]

7. Bond, T.C.; Doherty, S.J.; Fahey, D.W.; Forster, P.M.; Berntsen, T.; DeAngelo, B.J.; Flanner, M.G.; Ghan, S.; Kärcher, B.; Koch, D. Bounding the role of black carbon in the climate system: A scientific assessment. J. Geophys. Res. Atmos. 2013, 118, 5380-5552. [CrossRef]

8. Pawlyta, M.; Rouzaud, J.-N.; Duber, S. Raman microspectroscopy characterization of carbon blacks: Spectral analysis and structural information. Carbon 2015, 84, 479-490. [CrossRef]

9. Gelencsér, A. Carbonaceous Aerosol; Springer: Berlin, Germany, 2004; p. 350.

10. Bhandari, J.; China, S.; Chandrakar, K.K.; Kinney, G.; Cantrell, W.; Shaw, R.A.; Mazzoleni, L.R.; Girotto, G.; Sharma, N.; Gorkowski, K.; et al. Extensive soot compaction by cloud processing from laboratory and field observations. Sci. Rep. Nat. Res. 2019, 9, 11824. [CrossRef] [PubMed]

11. Pósfai, M.; Molnár, Á. Aeorosl particles in the atmosphere: A mineralogical introduction. In EMU Notes in Mineralogy; European Mineralogical Union: Université de Lille, France; Mineralogical Society of Great Britain and Ireland: London, UK, 2000; Volume 2, pp. 197-252.

12. Kis, V.K.; Pósfai, M.; Lábár, J.L. Nanostructure of atmospheric soot particles. Atmos. Environ. 2006, 40, 5533-5542. [CrossRef]

13. Sadezky, A.; Muckenhuber, H.; Grothe, H.; Niessner, R.; Pöschl, U. Raman microspectroscopy of soot and related carbonaceous materials: Spectral analysis and structural information. Carbon 2005, 43, 1731-1742. [CrossRef]

14. Jabłońska, M.; Janeczek, J. Identification of industrial point sources of airborne dust particles in an urban environment by a combined mineralogical and meteorological analyses: A case study from the Upper Silesian conurbation, Poland. Atmos. Pollut. Res. 2019, 10, 980-988. [CrossRef]

15. WHO Regional Office for Europe, Copenhagen, Denmark. Health Effects of Black Carbon. Available online: http://www. euro.who.int/en/health-topics/environment-and-health/air-quality / publications/2012/health-effects-of-black-carbon-2012 (accessed on 11 June 2021).

16. Fuzzi, S.; Gilardoni, S.; Kokhanovsky, A.A.; Di Nicolantonio, W.; Sonoyo, M.; Sano, I.; Nakata, M.; Tomasi, C.; Lanconelli, C. Aerosol and air quality. In Atmospheric Aerosols. Life Cycles and Effects on Air Quality and Climate; Tomasi, C., Fuzzi, S., Kokhanovsky, A., Eds.; Wiley Series in Atmospheric Physics and Remote Sensing; Wiley-VCH Verlag GmbH \& Co. KgaA: Weinheim, Germany, 2017; pp. 183-221.

17. Buseck, P.R.; Pósfai, M. Airborne minerals and related aerosol particles: Effects on climate and the environment. Proc. Natl. Acad. Sci. USA 1999, 96, 3372-3379. [CrossRef]

18. Chen, Y.; Shah, N.; Braun, A.; Huggins, F.E.; Huffman, G.P. Electron microscopy investigation of carbonaceous particulate matter generated by combustion of fossil fuels. Energy Fuels 2005, 19, 1644-1651. [CrossRef]

19. Li, W.J.; Shao, L.Y.; Buseck, P.R. Haze types in Beijing and the influence of agricultural biomass burning. Atmos. Chem. Phys. 2010, 10, 8119-8130. [CrossRef]

20. Tumolva, L.; Park, J.-Y.; Kim, J.; Miller, A.L.; Chow, J.C.; Watson, J.G.; Park, K. Morphological and elemental classification of freshly emitted soot particles and atmospheric ultrafine particles using the TEM/EDS. Aerosol Sci. Technol. 2010, 44, 202-215. [CrossRef]

21. Pawlyta, M.; Hercman, H. Transmission electron microscopy (TEM) as a tool for identification of combustion products: Application to black layers in speleothems. Ann. Soc. Geol. Pol. 2016, 86, 237-248. [CrossRef]

22. Escribano, R.; Sloan, J.J.; Siddique, N.; Sze, N.; Dudev, T. Raman spectroscopy of carbon-containing particles. Vib. Spectrosc. 2001, 26, 179-186. [CrossRef]

23. Commodo, M.; Joo, P.H.; De Falco, G.; Minutolo, P.; D'Anna, A.; Gülder, Ö.L. Raman spectroscopy of soot sampled in highpressure diffusion flames. Energy Fuels 2017, 31, 10158-10164. [CrossRef]

24. Ge, H.; Ye, Z.; He, R. Raman spectroscopy of diesel and gasoline engine-out soot using different laser power. J. Environ. Sci. 2019, 79, 74-80. [CrossRef] [PubMed]

25. Sze, S.-K.; Siddique, N.; Sloan, J.J.; Escribano, R. Raman spectroscopic characterization of carbonaceous aerosols. Atmos. Environ. 2001, 35, 561-568. [CrossRef]

26. Mertes, S.; Dippel, B.; Schwarzenböck, A. Quantification of graphitic carbon in atmospheric aerosol by Raman spectroscopy and first application for the determination of mass absorption efficiences. J. Aerosol Sci. 2004, 35, 347-361. [CrossRef] 
27. Ivleva, N.P.; McKeon, U.; Niessner, R.; Pöschl, U. Raman microspectroscopic analysis of size-resolved atmospheric aerosol particle samples collected with an ELPI: Soot, humic-like substances, and inorganic compounds. Aerosol Sci. Technol. 2007, 41, 655-671. [CrossRef]

28. Nordmann, S.W.; Birmili, W.; Weinhold, K.; Müller, K.; Spindler, G.; Wiedensohler, A. Measurements of the mass absorption cross section of atmospheric soot particles using Raman spectroscopy. J. Geophys. Res. Atmos. 2013, 118, 12075-12085. [CrossRef]

29. Catelani, T.; Pratesi, G.; Zoppi, M. Raman characterization of ambient airborne soot and associated mineral phases. Aerosol Sci. Technol. 2014, 48, 13-21. [CrossRef]

30. Ongeo. Geoportal. Available online: https:/ / ongeo.pl/geoportal/raciborz/zanieczyszczenie-powietrza (accessed on 5 December 2020).

31. Błaszczak, B.; Mathews, B. Characteristics of the carbonaceous matter in aerosol from selected urban and rural areas of Southern Poland. Atmosphere 2020, 11, 687. [CrossRef]

32. Rogula-Kozłowska, W.; Klejnowski, K.; Rogula-Kopiec, P.; Ośródka, L.; Krajny, E.; Błaszczak, B.; Mathews, B. Spatial and seasonal variability of the mass concentrations and chemical composition of PM2.5 in Poland. Air Qual. Atmos. Health 2014, 7, 41-58. [CrossRef]

33. Lünsdorf, N.K.; Lünsdorf, J.O. Evaluating Raman spectra of carbonaceous matter by automated, iterative curve-fitting. Int. J. Coal Geol. 2016, 160, 51-62. [CrossRef]

34. Goryl, M.; Banasik, K.; Smolarek-Lach, J.; Marynowski, L. Utility of Raman spectroscopy in estimates of the thermal maturity of Ediacaran organic matter: An example from the East European Craton. Geochemistry 2019, 79, 467-474. [CrossRef]

35. Rantitsch, G.; Bhattacharyya, A.; Schenk, J. Microstructural evolution of blast furnace coke during experimental heating-The IFORS approach. BHM Bergund Hüttenmännische Mon. 2019, 164, 257-260. [CrossRef]

36. Reizer, M.; Juda-Rezler, K. Explaining the high $\mathrm{PM}_{10}$ concentrations observed in Polish urban areas. Air Qual. Atmos. Health 2016, 9, 517-531. [CrossRef]

37. Klejnowski, K.; Janoszka, K.; Czaplicka, M. Characterization and seasonal variations of organic and elemental carbon and levoglucosan in $\mathrm{PM}_{10}$ in Krynica Zdroj, Poland. Atmosphere 2017, 8, 190. [CrossRef]

38. Zioła, N.; Błaszczak, B.; Klejnowski, K. Temporal variability of equivalent Black Carbon components in atmospheric air in Southern Poland. Atmosphere 2021, 12, 119. [CrossRef]

39. Khan, M.B.; Masiol, M.; Formenton, G.; Di Gilio, A.; de Gennaro, G.; Agostinelli, C.; Pavoni, B. Carbonaceous $\mathrm{PM}_{2.5}$ and secondary organic aerosol across the Venetto region (NE Italy). Sci. Total Environ. 2016, 542, 172-181. [CrossRef]

40. Sandrini, S.; Fuzzi, S.; Piazzalunga, A.; Prati, P.; Bonasoni, P.; Cavalli, F.; Bove, M.C.; Calvello, M.; Cappelletti, D.; Colombi, C.; et al. Spatial and seasonal variability of carbonaceous aerosol in Italy. Atmos. Environ. 2014, 99, 587-598. [CrossRef]

41. Putaud, J.-P.; van Dingenen, R.; Alastuey, A.; Bauer, H.; Birmili, W.; Cyrys, J.; Flentje, H.; Fuzzi, S.; Gehrig, R.; Hansson, H.C.; et al. A European aerosol phenomenology 3: Physical and chemical characteristics of particulate matter from 60 rural, urban, and kerbside sites across Europe. Atmos. Environ. 2010, 44, 1308-1320. [CrossRef]

42. Godec, R.; Čačkovič, M.; Šega, K. Winter mass concentrations of carbon species in $\mathrm{PM}_{10}, \mathrm{PM}_{2.5}$ and $\mathrm{PM}_{1}$ in Zagreb air, Croatia. Bull. Environ. Contam. Toxicol. 2012, 89, 1087-1090. [CrossRef]

43. Zhu, C.S.; Cao, J.J.; Tsai, C.J.; Shen, Z.X.; Liu, S.X.; Huang, R.J.; Zhang, N.N.; Wang, P. The rural carbonaceous aerosols in coarse, fine, and ultrafine particles during haze pollution in northwestern China. Environ. Sci. Pollut. Res. 2016, 23, 4569-4575. [CrossRef]

44. Titos, G.; del Águila, A.; Cazorla, A.; Lyamani, H.; Casquero-Vera, J.A.; Colombi, C.; Cuccia, E.; Gianelle, V.; Močnik, G.; Alastuey, A.; et al. Spatial and temporal variability of carboanceous aerosol: Assessing the impact of biomass burning in the urban environment. Sci. Total Environ. 2017, 578, 613-627. [CrossRef]

45. Li, X.; Jiang, L.; Bai, Y.; Yang, Y.; Liu, S.; Chen, X.; Xu, J.; Liu, Y.; Wang, Y.; Guo, X.; et al. Wintertime aerosol chemistry in Beijing during haze period: Significant contribution from secondary formation and biomass burning emission. Atmos. Res. 2019, 218, 25-33. [CrossRef]

46. Gilardoni, S.; Massoli, P.; Marinoni, A.; Mazzoleni, C.; Freedman, A.; Lonati, G.; De Iullis, S.; Gianelle, V. Spatial and temporal variability of carbonaceous absorption in the Po valley. Aerosol Air Qual. Res. 2020, 20, 2624-2639. [CrossRef]

47. Nasdala, L.; Smith, D.C.; Kaindl, R.; Zieman, M.A. Raman spectroscopy: Analytical perspectives in mineralogical research. In EMU Notes in Mineralogy; Beran, A., Libowitzky, E., Eds.; Eötvös University Press: Budapest, Hungary, 2004; Volume 6, pp. 281-343.

48. Jawarhi, T.; Roid, A.; Casado, I. Raman spectroscopic characterization of some commercially available carbon black materials. Carbon 1995, 33, 1561-1565. [CrossRef]

49. Patel, M.; Ricardo, C.L.; Scardi, P.; Aswath, P.B. Morphology, structure and chemistry of extracted diesel soot-Part I: Transmission electron microscopy, Raman spectroscopy, X-ray photoelectron spectroscopy and synchrotron X-ray diffraction study. Tribol. Int. 2012, 52, 29-39. [CrossRef]

50. Henry, D.G.; Jarvis, I.; Gillmore, G.; Stephenson, M. A rapid method for determining organic matter maturity using Raman spectroscopy: Application to carboniferous organic-rich mudstones and coals. Int. J. Coal Geol. 2019, 203, 87-98. [CrossRef]

51. Ferralis, N.; Matys, E.F.; Knoll, A.H.; Hallmann, C.; Summons, R.E. Rapid, direct and non-destructive assessment of fossil organic matter via microRaman spectroscopy. Carbon 2016, 108, 440-449. [CrossRef]

52. Khatibi, S.; Abarghani, A.; Liu, K.; Guedes, A.; Valentim, B.; Ostadhassan, M. Backtracking to parent maceral from produced bitumen with Raman spectroscopy. Minerals 2020, 10, 679. [CrossRef] 
53. Romero-Sarmiento, M.-F.; Rouzaud, J.-N.; Bernard, S.; Deldicque, D.; Thomas, M.; Littke, R. Evolution of Barnett Shale organic carbon structure and nanostructure with increasing maturation. Org. Geochem. 2014, 71, 7-16. [CrossRef]

54. Beyssac, O.; Goffé, B.; Petitet, J.-P.; Froigneux, E.; Moreau, M.; Rouzaud, J.-N. On the characterization of disordered and heterogeneous carbonaceous materials by Raman spectroscopy. Spectrochim. Acta Part A 2003, 59, 2267-2276. [CrossRef]

55. Sharma, M.; Singh, G.; Vaish, R. Diesel soot coated non-woven fabric for oil-water separation and adsorption applications. Sci. Rep. 2019, 9, 8503. [CrossRef] [PubMed]

56. Sharma, V.U.D.; Gangopadhyay, A.; Aswath, P. Structure and chemistry of crankcase and exhaust soot extracted from diesel engines. Carbon 2016, 103, 327-338. [CrossRef]

57. Liu, Y.; Song, C.L.G.; Wang, X.; Li, N. Virgin and extracted soots in premixed methane flames: A comparison of surface functional groups, graphitization degree, and oxidation reactivity. Energy Fuels 2017, 31, 6413-6421. [CrossRef]

58. Pfau, S.A.; La Rocca, A.; Haffner-Staton, E.; Rance, G.A.; Fay, M.W.; Brough, R.J.; Malizia, S. Comparative nanostructure analysis of gasoline turbocharged direct injection and diesel soot-in-oil with carbon black. Carbon 2018, 139, 342-352. [CrossRef]

59. Zhang, X.; Lyu, G.; Song, C.; Qiao, Y. Effects of biodiesel addition on the physical properties and reactivity of the exhaust soot particles from diesel engine. Energies 2020, 13, 4206. [CrossRef]

60. Schito, A.; Romano, C.; Corrado, S.; Grido, D.; Poe, B. Diagenetic thermal evolution of organic matter by Raman spectroscopy. Org. Geochem. 2017, 106, 57-67. [CrossRef]

61. Kouketsu, Y.; Mizukami, T.; Mori, H.; Endo, S.; Aoya, M.; Hara, H.; Nakamura, D.; Wallis, S. A new approach to develop the Raman carbonaceous material geothermometer for low-grade metamorphism using peak width. Isl. Arc 2014, 23, 33-50. [CrossRef]

62. Opoczyński, K. Summary of GPR2015 Results Obtained for the Domestic Road Network outside Urban Areas (In Polish: Synteza Wyników GPR15 na Zamiejskiej Sieci Dróg Krajowych). Available online: www.gddkia.gov.pl/userfiles/articles/g/generalnypomiar-ruchu-w-2015_15598//SYNTEZA/Synteza_GPR2015.pdf (accessed on 29 January 2021). 